\title{
Characterisation of Electrodeposited and Heat-Treated Ni-Mo-P Coatings
}

\author{
Régis L. Melo, Paulo N. S. Casciano, Adriana N. Correia and Pedro de Lima-Neto* \\ Departamento de Química Analítica e Físico-Química, Universidade Federal do Ceará, \\ Campus do Pici, Bloco 940, 60455-960 Fortaleza-CE, Brazil
}

\begin{abstract}
A eletrodeposição e as propriedades de dureza e resistência à corrosão de eletrodepósitos de $\mathrm{Ni}-\mathrm{Mo}-\mathrm{P}$ foram estudadas. A caracterização das camadas foi feita por microscopia eletrônica de varredura, difração de raios $\mathrm{X}$ e energia dispersiva de raios $\mathrm{X}$. Os ensaios de corrosão foram feitos à temperatura ambiente em $\mathrm{NaCl} 10^{-1} \mathrm{~mol} \mathrm{dm}^{-3}$ e por polarização linear potenciodinâmica. Camadas amorfas de Ni-Mo-P foram obtidas e a composição destas mostrou ser dependente da composição do banho, da densidade de corrente aplicada e da temperatura do banho. A dureza das camadas de Ni-Mo-P mostrou ser dependente dos teores de Mo e $\mathrm{P}$ e que a ausência de trincas é um requerimento necessário para obter eletrodepósitos de $\mathrm{Ni}-\mathrm{Mo}-\mathrm{P}$ com boas propriedades de dureza. A dureza das camadas tratadas termicamente aumentou com a temperatura de tratamento térmico devido à precipitação das fases $\mathrm{Ni}, \mathrm{Ni}_{3} \mathrm{P}$ e NiMo durante o tratamento térmico. A resistência à corrosão dos eletrodepósitos de $\mathrm{Ni}-\mathrm{Mo}-\mathrm{P}$ aumentou com o teor de $\mathrm{P}$ na camada. A camada $\mathrm{Ni}_{78} \mathrm{Mo}_{10} \mathrm{P}_{12}$ apresentou os maiores valores de dureza a a maior resistência à corrosão. A adição de $\mathrm{P}$ mostrou ser benéfica para as propriedades de dureza e resistência à corrosão de eletrodepósitos de Ni-Mo.
\end{abstract}

The electrodeposition, hardness and corrosion resistance properties of Ni-Mo-P coatings were investigated. Characterisations of the electrodeposited coatings were carried out using scanning electron microscopy, X-ray diffraction and energy dispersive X-ray analysis techniques. Corrosion tests were performed at room temperature in $10^{-1} \mathrm{~mol} \mathrm{dm}^{-3} \mathrm{NaCl}$ solutions and by potentiodynamic linear polarisation. Amorphous Ni-Mo-P coatings were successfully obtained by electrodeposition using direct current. The coating composition showed to be dependent on the bath composition, current density and bath temperature. Both $\mathrm{P}$ and Mo contents contribute for the hardness properties of the $\mathrm{Ni}-\mathrm{Mo}-\mathrm{P}$ coatings and the absence of cracks is a requirement to produce electrodeposited Ni-Mo-P coatings with good hardness properties. The hardness values increase with heat-treatment temperature due to the precipitation of $\mathrm{Ni}, \mathrm{Ni}_{3} \mathrm{P}$ and $\mathrm{NiMo}$ phases during the heat treatment. The corrosion resistance of the electrodeposited $\mathrm{Ni}-\mathrm{Mo}-\mathrm{P}$ amorphous coatings increases with $\mathrm{P}$ content in the layer. Among the electrodeposited Ni-Mo-P amorphous coatings, $\mathrm{Ni}_{78} \mathrm{Mo}_{10} \mathrm{P}_{12}$ presented the best hardness and corrosion-resistance properties. The results showed that the addition of $\mathrm{P}$ is beneficial for the hardness and corrosion resistance properties of the Ni-Mo-based coatings.

Keywords: Ni-Mo-P, electrodeposition, amorphous, corrosion, hardness

\section{Introduction}

There is currently great interest in the study of the electrodeposition of $\mathrm{Ni}-\mathrm{Mo}$ coatings, because they are considered to be corrosion-resistant coatings, ${ }^{1-4}$ they are electrocatalysts for hydrogen and oxygen evolution reactions, ${ }^{5-8}$ and they present good hardness properties. ${ }^{9}$

Recently, we showed that electrodeposited Ni-Mo coatings presented inferior corrosion-resistance and

\footnotetext{
*e-mail: pln@ufc.br
}

hardness properties in comparison to electrodeposited $\mathrm{Cr}$ coatings. ${ }^{10}$ However, after heat treatment at temperature higher than $100{ }^{\circ} \mathrm{C}$, these coatings presented superior hardness properties in comparison to the heat-treated $\mathrm{Cr}$ coatings. These results indicated that $\mathrm{Ni}-\mathrm{Mo}$ coatings could be a potential substitutes for chromium coatings in industrial applications in which operational temperatures higher than $100{ }^{\circ} \mathrm{C}$ and good hardness properties are required. ${ }^{10}$ Another point that supports a possible replacement of the $\mathrm{Cr}$ coatings by Ni-Mo coatings is that the industrial production of electrodeposited Ni-Mo coatings could produce 
environmentally harmless wastewater, since molybdenum is a non-toxic metal for the aquatic environment, ${ }^{11}$ while the industrial chromium electroplating process requires the use of carcinogenic $\mathrm{Cr}^{6+}$ ions. However, the electrodeposition of Ni-Mo coatings is limited to a maximum of 17 at.\% of Mo in the layer, since electrodeposits with Mo content higher than $17 \%$ were cracked, which compromised the corrosion-resistance and hardness properties of the $\mathrm{Ni}-\mathrm{Mo}$ coatings. ${ }^{10,12}$ Thus, the challenge in the research of electrodeposition of Ni-Mo-based coatings is to obtain electrodeposits that are non-cracked, even with Mo content in the layer higher than 17 at.\%.

On the other hand, amorphous metallic alloys present interesting mechanical, magnetic and electrochemical properties. These materials have shown higher corrosion resistance than crystalline alloys with the same composition, which encourages the interest in producing anticorrosive amorphous coatings. The physicochemical processing and technical application of amorphous metallic alloys have previously been reviewed by some authors. ${ }^{13-16}$

This class of coating can be produced by sputtering, electroless and electrodeposition techniques. Among these techniques, electrodeposition is very suitable to produce amorphous coatings because it permits working with substrates in different shapes and geometries and makes it possible to control the thickness and the composition of the coating by only changing the electrodeposition parameters. The amorphous character of an electrodeposited coating is usually achieved by the codeposition of the elements of the iron group ( $\mathrm{Fe}, \mathrm{Ni}$ and $\mathrm{Co}$ ) with an element, that can be a metal such as Mo and W or a metalloid such as P or B, which provokes defects in the crystal lattice of the coating, leading to the absence of a crystallographic structure in the electrodeposited coating. ${ }^{8,10,12,17-22}$ Among them, $\mathrm{P}$ is the more usual element to be codeposited with the elements of the iron group because it improves the corrosion-resistance properties of the electrodeposited coatings due to the fact that in aqueous medium this element produces a protective surface film formed by the phosphate anion, which kinetically limits the dissolution of the amorphous coatings such as Ni-P and $\mathrm{Co}-\mathrm{P}$ electrodeposits. ${ }^{22}$ Another important requirement to obtain amorphous electrodeposits is the composition of coating. For instance, binary $\mathrm{Ni}-\mathrm{P}$ and $\mathrm{Co}-\mathrm{P}$ electrodeposits are amorphous if the $\mathrm{P}$ content exceeds 14 at. $\% .^{22}$

Therefore, the codeposition of $\mathrm{P}$ with $\mathrm{Ni}$ and $\mathrm{Mo}$ can produce electrodeposits with good corrosion resistance and good hardness properties. Furthermore, little is known about the influence of operational parameters on the composition of Ni-Mo-P coatings, on their corrosion resistance, or about the influence of heat-treatment temperature on the crystal structure and hardness properties of $\mathrm{Ni}-\mathrm{Mo}-\mathrm{P}$ coatings.
Thus, the aim of this work is to study the effect of $\mathrm{P}$ content in the corrosion resistance and microhardness properties of the electrodeposited Ni-Mo-P amorphous coatings. An analysis of the influence of thermal treatments on the crystal structure and on hardness properties of these coatings is also present.

\section{Experimental}

\section{Electrodeposition}

Solutions were prepared from chemicals of analyticalgrade purity dissolved in water purified with a Millipore Milli-Q system. Ni-Mo-P coatings were electrodeposited on a disc-shaped $\mathrm{Cu}$ substrate embedded in epoxy resin, with a geometric area of approximately $2 \mathrm{~cm}^{2}$ of exposure. The electrodepositions were performed in a single-compartment Pyrex glass cell with a Teflon cover containing holes to affix the $\mathrm{Cu}$ cathode and the platinum-mesh anode. Prior to alloy plating, the $\mathrm{Cu}$ surfaces were polished with 240 , 400 and $600 \mathrm{SiC}$ emery paper, degreased in a hot $\mathrm{NaOH}$ solution, rinsed in distilled water, etched in $15 \% \mathrm{HCl}$ solution and, lastly, rinsed with distilled water. Table 1 gives the composition of the Ni-Mo-P plating solutions and the operational parameters used to electrodeposit these coatings.

Table 1. Composition of the baths utilised in the electrodeposition ( $\mathrm{pH} 10)$

\begin{tabular}{lccc}
\hline \multirow{2}{*}{ Reagent } & \multicolumn{3}{c}{ Concentration / $\left(\mathrm{mol} \mathrm{dm}^{-3}\right)$} \\
\cline { 2 - 4 } & Bath 1 & Bath 2 & Bath 3 \\
\hline $\mathrm{NiSO}_{4} \cdot \mathrm{H}_{2} \mathrm{O}$ & 0.2 & 0.2 & 0.2 \\
$\mathrm{Na}_{2} \mathrm{MoO}_{4} \cdot 2 \mathrm{H}_{2} \mathrm{O}$ & 0.02 & 0.02 & 0.02 \\
$\mathrm{NaPH}_{2} \mathrm{O}_{2}$ & 0.02 & 0.04 & 0.08 \\
$\mathrm{Na}_{3} \mathrm{C}_{6} \mathrm{H}_{5} \mathrm{O}_{7} \cdot 2 \mathrm{H}_{2} \mathrm{O}$ & 0.1 & 0.10 & 0.10 \\
\hline
\end{tabular}

Operational deposition parameters: $\mathrm{pH} 10$ (adjusted with ammonia); plating temperature $=$ room temperature $\left(\mathrm{ca} .30^{\circ} \mathrm{C}\right), 50^{\circ} \mathrm{C}$ and $70{ }^{\circ} \mathrm{C}$; electrodeposition current density $=50,75$ and $100 \mathrm{~mA} \mathrm{~cm}^{-2}$; total charge deposition $=250 \mathrm{C}$ and $2000 \mathrm{C}$.

\section{Heat treatment}

As-electrodeposited $\mathrm{Cu} / \mathrm{Ni}-\mathrm{Mo}-\mathrm{P}$ samples were annealed in an $\mathrm{N}_{2}$ atmosphere at $100,200,400$ and $600^{\circ} \mathrm{C}$, using a heating rate of $10^{\circ} \mathrm{C} \mathrm{min}-1$ from room temperature to the desired temperature plateau, where they were held for $1 \mathrm{~h}$. After the annealing process, the samples were cooled under the furnace atmosphere until to room temperature.

\section{Physical and chemical characterisations}

The surface morphology of the electrodeposits was analysed by a Philips XL-30 scanning electron microscope 
(SEM). The coating composition was analysed by energy dispersive X-ray (EDX) apparatus attached to the SEM. The coating crystal phase structure was analysed by X-ray diffraction (XRD) using a Philips model X'Pert pro diffractometer with $\mathrm{Cu} \mathrm{K} \alpha$ radiation $(\lambda=1.54 \AA)$ at $40 \mathrm{KV}$ and $40 \mathrm{~mA}$ and an incident angle of $3^{\circ}$. The main peaks observed in the diffractograms were compared with XRD data from the JCPDS (Joint Committee of Powder Diffraction Standards). Microhardness measurements were carried out using a Shimadzu model HMV-2-Series microhardness tester with a diamond pyramid indenter at a load of $10 \mathrm{~g}$, which was maintained for $30 \mathrm{~s}$. An average of 10 readings was taken to obtain the hardness values of the coatings. To prevent the substrate from affecting the microhardness measurements, samples were obtained with a total electrodeposition charge of $2000 \mathrm{C}$.

\section{Corrosion tests}

The corrosion behaviour of as-electrodeposited $\mathrm{Ni}-\mathrm{Mo}-\mathrm{P}$ coatings was evaluated by potentiodynamic linear polarisation (PLP) technique with a scan rate of $1 \mathrm{mV} \mathrm{s}^{-1}$ in $0.1 \mathrm{~mol} \mathrm{dm}^{-3} \mathrm{NaCl}$ aqueous solutions with a natural $\mathrm{pH}$ of 6.5. A potentiostat/galvanostat AUTOLAB PGSTAT 30, linked to a PC microcomputer and controlled by GPES and FRA software, was used for the acquisition of the electrochemical data.

\section{Results and Discussion}

\section{Influence of the plating parameters}

The dependences of Mo and P contents in the electrodeposited coatings with the operational plating parameters are shown in Figure 1. The values shown in this figure correspond to average values of at least duplicate samples obtained in each operational condition. It can be observed that the increase in the temperature of the plating process leads to an increase in the Mo content in the layer, which decreases with the $\mathrm{NaPH}_{2} \mathrm{O}_{2}$ concentration in the plating solution and with the deposition current density. In each bath, the lowest Mo content is observed for the coatings obtained at $30{ }^{\circ} \mathrm{C}$, and at this deposition temperature the Mo content is approximately independent of the deposition current density. For the layers electrodeposited at $50{ }^{\circ} \mathrm{C}$ and $70{ }^{\circ} \mathrm{C}$, the Mo content decreases with deposition current density for the layers obtained from bath 1 and bath 2. For the layers obtained from bath 3 , in each studied temperature, the Mo content remains approximately constant for the deposition current density values lower than $100 \mathrm{~mA} \mathrm{~cm}{ }^{-2}$, followed by a decrease for those coatings electrodeposited at $100 \mathrm{~mA} \mathrm{~cm}^{-2}$. The observed dependence of the Mo content in the coating with the deposition current density suggests that the Mo codeposition process is limited by mass transport of the molybdate ion to the electrode surface, which is in close agreement with results reported by Marlot $e t$ al. ${ }^{23}$ while the dependence with temperature is explained as a consequence of the increase of mass transport due to the increase in the ionic mobility with the rise of temperature.

Figure 1 shows that $\mathrm{P}$ content in the electrodeposited coatings increases with the $\mathrm{NaPH}_{2} \mathrm{O}_{2}$ concentration in the plating solution. However, distinct dependences for $\mathrm{P}$ content in the layer with the temperature and with deposition current density can be observed. Initially, all coatings electrodeposited at $25 \mathrm{~mA} \mathrm{~cm}{ }^{-2}$ show that $\mathrm{P}$ content in the layer decreases with the temperature, while those obtained at higher deposition current density values tend to increase with temperature. In addition, while the deposition current density has little effect on $\mathrm{P}$ content in the coatings obtained at $30^{\circ} \mathrm{C}$, it influences the $\mathrm{P}$ content in the layers obtained at higher temperatures, since $\mathrm{P}$ content in the coatings tends to increase with the deposition current density.

For further study, Ni-Mo-P coatings were selected in order to evaluate the influence of $\mathrm{P}$ content on the hardness and corrosion properties of the Ni-Mo-P coatings. The selected samples are listed in Table 2.

Table 2. List of the selected electrodeposited Ni-Mo-P amorphous coatings

\begin{tabular}{lccc}
\hline Bath & $\mathrm{i} /\left(\mathrm{mA} \mathrm{cm}^{-2}\right)$ & Bath Temperature $/{ }^{\circ} \mathrm{C}$ & Composition / at. \\
\hline 1 & 25 & 70 & $\mathrm{Ni}_{81} \mathrm{Mo}_{18} \mathrm{P}_{1}$ \\
1 & 50 & 70 & $\mathrm{Ni}_{73} \mathrm{Mo}_{21} \mathrm{P}_{6}$ \\
1 & 100 & 70 & $\mathrm{Ni}_{83} \mathrm{Mo}_{10} \mathrm{P}_{7}$ \\
2 & 50 & 50 & $\mathrm{Ni}_{90} \mathrm{Mo}_{5} \mathrm{P}_{8}$ \\
3 & 100 & 70 & $\mathrm{Ni}_{82} \mathrm{Mo}_{5} \mathrm{P}_{12}$ \\
3 & 75 & 70 & $\mathrm{Ni}_{78} \mathrm{Mo}_{10} \mathrm{P}_{12}$ \\
\hline
\end{tabular}

Physical characterisation

Figure 2 shows the X-ray diffractograms obtained for the selected as-electrodeposited Ni-Mo-P coatings. All diffractograms present a broad peak around $2 \theta$ of $45^{\circ}$, indicating that amorphous $\mathrm{Ni}-\mathrm{Mo}-\mathrm{P}$ coatings were successfully produced under every operational condition studied here. These results are in close accordance with those already published in the literature for electroless Ni-Mo-P amorphous coatings. ${ }^{24}$

The surface morphologies of the selected as-electrodeposited $\mathrm{Ni}-\mathrm{Mo}-\mathrm{P}$ coatings are shown in 
A) Bath 1

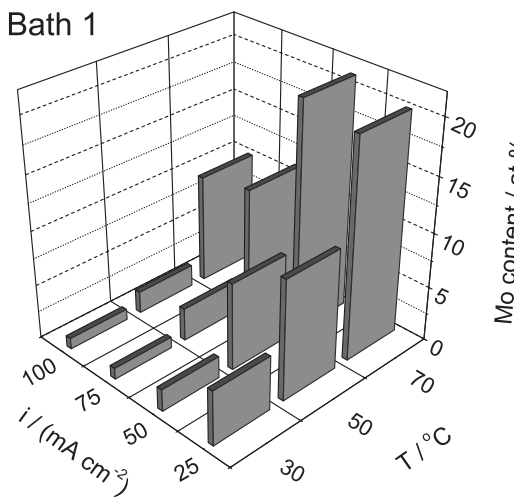

C) Bath 2

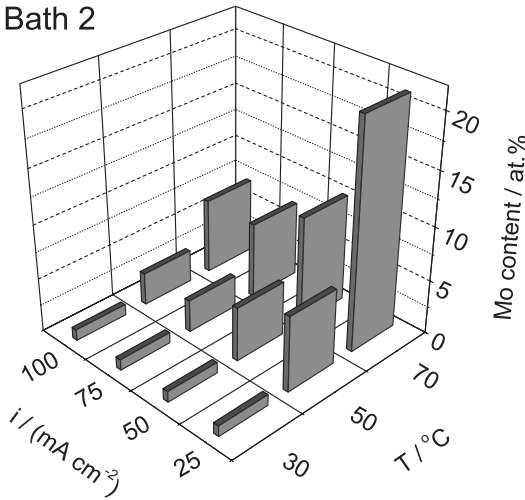

E) Bath 3

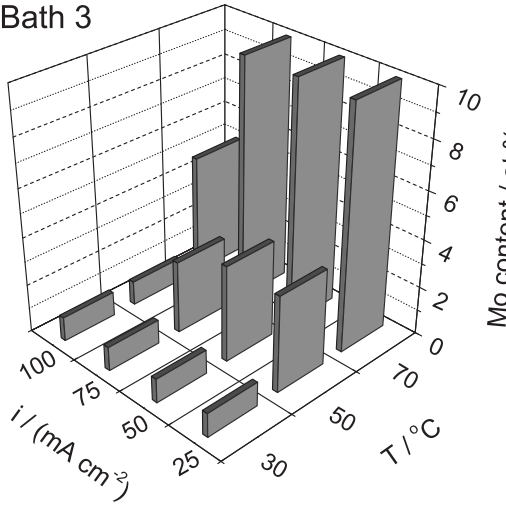

B) Bath 1

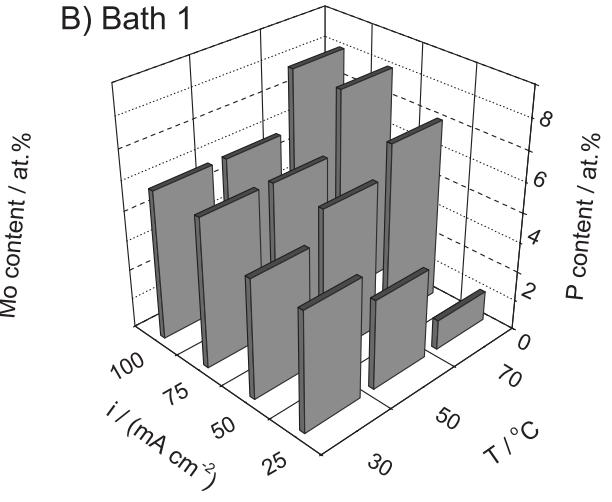

D) Bath 2
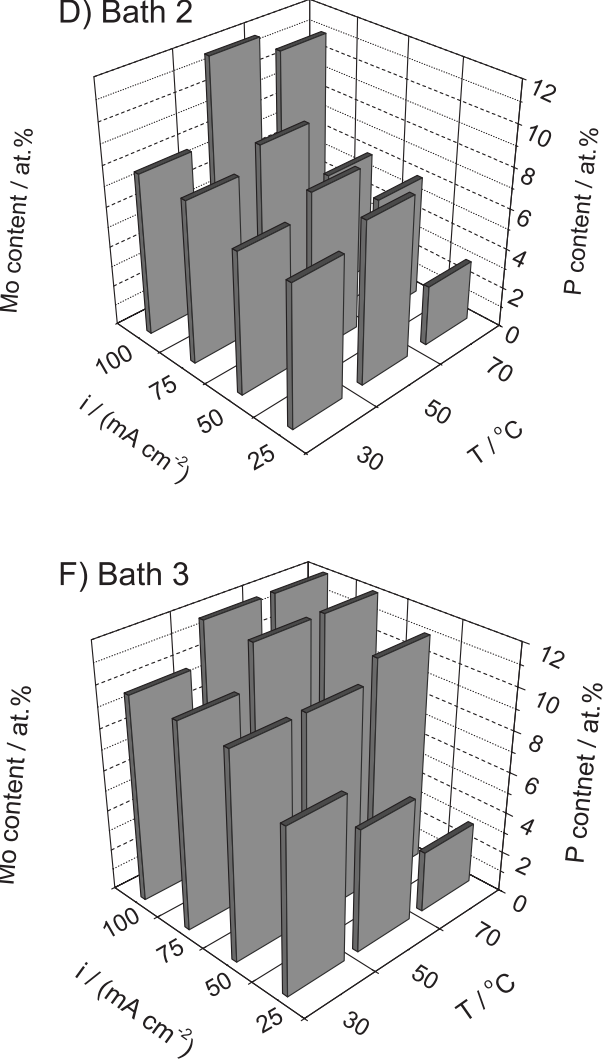

Figure 1. Influence of the bath composition, applied deposition current density and bath temperature in the composition of the electrodeposited Ni-Mo-P coatings.

Figure 3. Initially, the electrodeposited coating that contains 18 at.\% of Mo and 1 at.\% of P (Figure 3A) is cracked, while the surface morphologies of the other selected $\mathrm{Ni}-\mathrm{Mo}-\mathrm{P}$ coatings are similar (Figures 3B-3F), presenting spherical nodules distributed on the surface, and no cracks. The existence of cracks in the electrodeposited $\mathrm{Ni}_{81} \mathrm{Mo}_{18} \mathrm{P}_{1}$ layer is related to the surface relaxation of internal tensile stress in the coating, and these cracks certainly compromise the corrosion-resistance performance of this layer, since they allow the permeation of electrolyte to the substrate. The observed spherical nodules are explained as a consequence of the growth of secondary nuclei on top of the first layer that was formed on the substrate surface. It has previously been reported in the literature ${ }^{10,12}$ that cracked Ni-Mo electrodeposits were obtained when the Mo content in the layer was higher than 17 at.\%. Thus, Figure 3A shows that 1 at. $\%$ of $\mathrm{P}$ is not enough to avoid the formation of a cracked $\mathrm{Ni}-\mathrm{Mo}-\mathrm{P}$ layer which can compromise the corrosion resistance and hardness properties of this coating. On the other hand, the others SEM images (Figures 3B-3F) show the beneficial effect of the increase of the $\mathrm{P}$ content in the coating, since the existence of a cracked morphology is not observed for the coatings containing P higher than 1 at. $\%$, even for those coatings containing Mo higher than 17 at. $\%$. 
Finally, these SEM images shows that the addition of $\mathrm{P}$ makes possible to overcome one of the problems associated with the electrodeposition of Ni-Mo-based coatings, which is the arisen of a cracked morphology when the Mo content in the coating exceeds 17 at.\%.

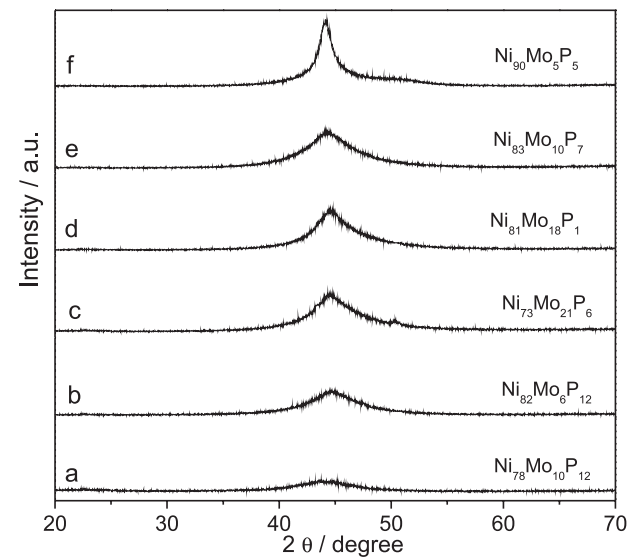

Figure 2. X-ray diffractograms of the electrodeposited Ni-Mo-P coatings.
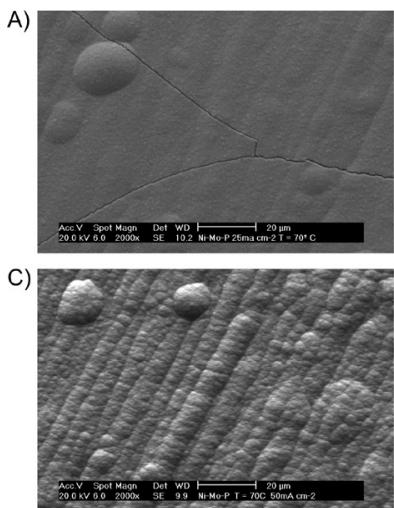

E)
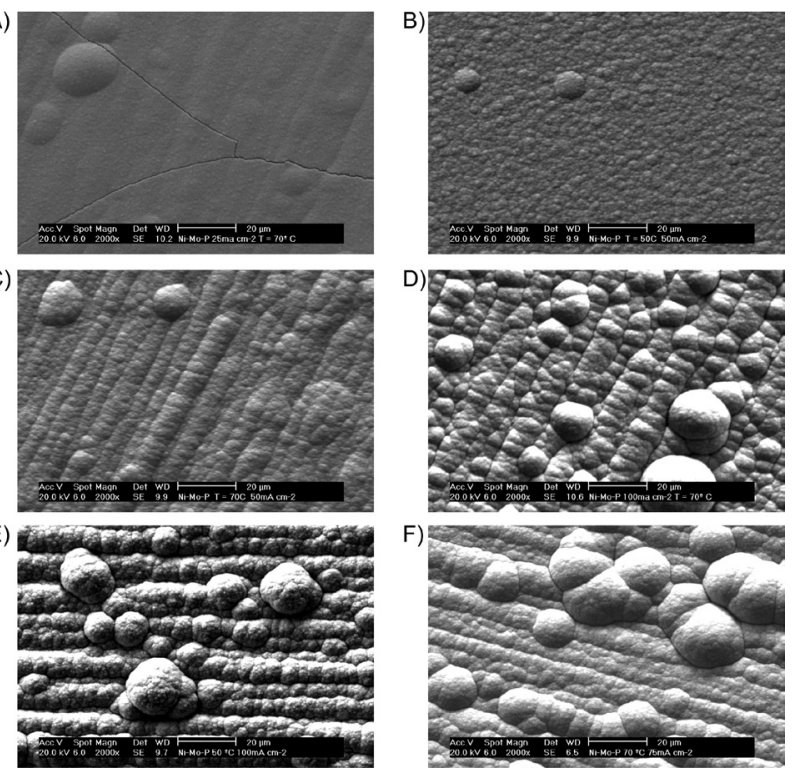

Figure 3. SEM images of the electrodeposited $\mathrm{Ni}_{81} \mathrm{Mo}_{18} \mathrm{P}_{1}(\mathrm{~A}), \mathrm{Ni}_{90} \mathrm{Mo}_{5} \mathrm{P}_{5}$ (B), $\mathrm{Ni}_{73} \mathrm{Mo}_{21} \mathrm{P}_{6}(\mathrm{C}), \mathrm{Ni}_{83} \mathrm{Mo}_{10} \mathrm{P}_{7}$ (D), $\mathrm{Ni}_{82} \mathrm{Mo}_{6} \mathrm{P}_{12}(\mathrm{E})$ and $\mathrm{Ni}_{78} \mathrm{Mo}_{10} \mathrm{P}_{12}(\mathrm{~F})$ amorphous coatings.

Hardness measurements were carried out in order to evaluate the influence of the coating composition and the influence of heat-treatment temperature on the hardness properties of the Ni-Mo-P coatings. Figure 4 shows the graph of the relationship between the compositions of the as-electrodeposited Ni-Mo-P layers and the hardness of the coatings. Initially, it can be observed that the lowest hardness value is presented by the $\mathrm{Ni}_{81} \mathrm{Mo}_{18} \mathrm{P}_{1}$, which shows the deleterious effect of the cracked morphology on the hardness properties. For the no cracked Ni-Mo-P coatings, a change from $190 \mathrm{Hv}$ to $298 \mathrm{Hv}$ is observed for the samples $\mathrm{Ni}_{90} \mathrm{Mo}_{5} \mathrm{P}_{5}$ and $\mathrm{Ni}_{76} \mathrm{Mo}_{21} \mathrm{P}_{6}$, respectively. For higher $\mathrm{P}$ content, little change in the hardness values is observed and the highest hardness value of $309 \mathrm{Hv}$ is presented by the $\mathrm{Ni}_{78} \mathrm{Mo}_{10} \mathrm{P}_{12}$ coating. In addition, coatings with higher Mo content, but with low $\mathrm{P}$ content such as $\mathrm{Ni}_{82} \mathrm{Mo}_{21} \mathrm{P}_{6}$ have similar hardness to the layers with lower Mo content but with higher $\mathrm{P}$ content such as $\mathrm{Ni}_{78} \mathrm{Mo}_{10} \mathrm{P}_{12}$. These results suggest that both $\mathrm{P}$ and Mo contents contribute for the hardness properties of the Ni-Mo-P coatings and that the absence of cracks is a requirement to produce electrodeposited Ni-Mo-P coatings with good hardness properties. Comparing these hardness values to those reported in the literature for electrodeposited Ni-Mo coatings, ${ }^{10}$ the electrodeposited $\mathrm{Ni}_{78} \mathrm{Mo}_{10} \mathrm{P}_{12}$ amorphous coatings present higher hardness values than the as-electrodeposited $\mathrm{Ni}_{87} \mathrm{Mo}_{13}$, which is about $287 \mathrm{Hv}$. However, the hardness values presented by the aselectrodeposited $\mathrm{Ni}-\mathrm{Mo}-\mathrm{P}$ are lower than that reported in the literature for the as-electrodeposited $\mathrm{Cr}$ coating, which is about 800 Hv. ${ }^{10}$

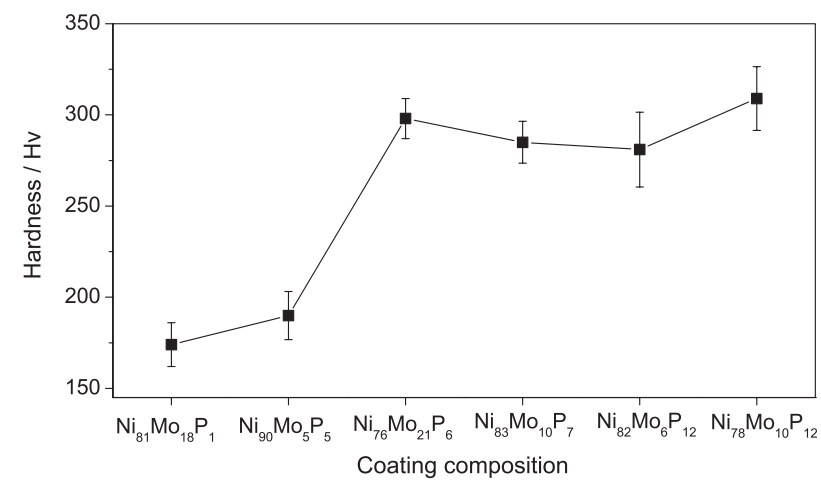

Figure 4. Variation of the hardness properties with the coating composition.

From the results shown in Figure 4, the sample $\mathrm{Ni}_{78} \mathrm{Mo}_{10} \mathrm{P}_{12}$ was selected in order to evaluate the influence of the heat treatment in the hardness of the coating and in Table 3 is listed the hardness values for $\mathrm{Ni}_{78} \mathrm{Mo}_{10} \mathrm{P}_{12}$ coatings heat-treated at the selected temperature. This Table shows that the hardness of the $\mathrm{Ni}_{78} \mathrm{Mo}_{10} \mathrm{P}_{12}$ coatings increases with the heat-treatment temperature. Similar trends have previously been reported for $\mathrm{Ni}-\mathrm{Mo}^{10}$ and $\mathrm{Ni}-\mathrm{W},{ }^{25}$ as well

Table 3. Hardness values of the $\mathrm{Ni}_{78} \mathrm{Mo}_{10} \mathrm{P}_{12}$ coatings heat-treated at selected temperatures

\begin{tabular}{cc}
\hline Heat Treatment Temperature $/{ }^{\circ} \mathrm{C}$ & Hardness $/ \mathrm{Hv}$ \\
\hline 100 & 287 \\
200 & 549 \\
400 & 797 \\
600 & 1041 \\
\hline
\end{tabular}


for similar systems such as $\mathrm{Ni}-\mathrm{W}-\mathrm{P}^{26}$ and $\mathrm{Ni}-\mathrm{Cr}-\mathrm{P}^{27}$ In order to understand the hardness behaviour of the $\mathrm{Ni}_{78} \mathrm{Mo}_{10} \mathrm{P}_{12}$ coating with the heat-treatment temperature, $\mathrm{X}$-ray diffractograms were obtained for the heat-treated samples, and they are shown in Figure 5.

The diffractograms of the samples heat-treated at $100{ }^{\circ} \mathrm{C}$ and $200{ }^{\circ} \mathrm{C}$ present similar X-ray diffraction patterns as the as-electrodeposited $\mathrm{Ni}_{78} \mathrm{Mo}_{10} \mathrm{P}_{12}$. The diffractogram of the sample heat-treated at $400{ }^{\circ} \mathrm{C}$ shows that the broad peak around $2 \theta$ of $45^{\circ}$ is better defined, as well as two new broad peaks at around $2 \theta$ of $51^{\circ}$ and $75^{\circ}$ and two well-defined peaks around $2 \theta$ of $35^{\circ}$ and $60^{\circ}$. The two broad peaks around $2 \theta$ of $45^{\circ}$ and $51^{\circ}$ are related to the nickel diffraction peaks. The broad peak around $2 \theta$ of $75^{\circ}$ is related to Ni-Mo diffraction peak. The peaks at $2 \theta$ of $35^{\circ}$ and $60^{\circ}$ are related to the $\mathrm{Ni}_{3} \mathrm{P}$ diffraction peaks. These results are in close agreement with the work of Koiwa et al. ${ }^{28}$ that studied the effect of the heat treatment on the electroless-deposited $\mathrm{Ni}-\mathrm{Mo}-\mathrm{P}$ amorphous coatings and showed that the $\mathrm{Ni}_{3} \mathrm{P}$ and $\mathrm{Ni}-\mathrm{Mo}$ phases were present in the sample heat-treated at $400{ }^{\circ} \mathrm{C}$. Thus, these results suggest that the heat-treatment temperature of $400{ }^{\circ} \mathrm{C}$ leads to precipitation of $\mathrm{Ni}, \mathrm{Ni}_{3} \mathrm{P}$ and $\mathrm{Ni}-\mathrm{Mo}$ phases on the $\mathrm{Ni}-\mathrm{Mo}-\mathrm{P}$ amorphous matrix. The diffractogram of the $\mathrm{Ni}_{78} \mathrm{Mo}_{10} \mathrm{P}_{12}$ sample heat-treated at $600{ }^{\circ} \mathrm{C}$ shows the diffraction peaks with better definition, indicating the crystallisation of the $\mathrm{Ni}_{78} \mathrm{Mo}_{10} \mathrm{P}_{12}$ and that the precipitation of new crystalline phases do not occur. Finally, the crystallographic structure that arises from the amorphous structure with the increase of the heat-treatment temperature, mainly for temperatures higher than $400{ }^{\circ} \mathrm{C}$, occurs due to separation of these crystal phases during heat treatment from the amorphous phase.

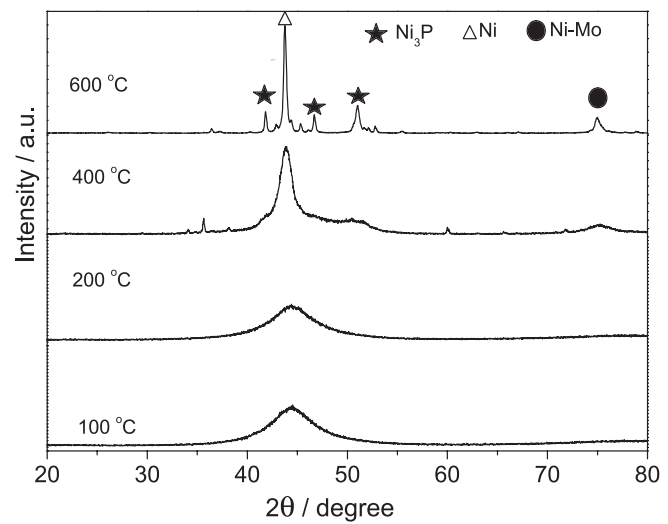

Figure 5. Evolution of the X-ray diffractograms for $\mathrm{Ni}_{78} \mathrm{Mo}_{10} \mathrm{P}_{12}$ coatings with heat-treatment temperature.

From the X-ray analyses, the behaviour of the hardness with the heat-treatment temperature for the $\mathrm{Ni}_{78} \mathrm{Mo}_{10} \mathrm{P}_{12}$ coatings can be explained by the fact that, with the increase of heat-treatment temperature, an increase occurs in the number of crystals separated from the amorphous matrix, and the new crystal phases that form during the heat treatment favour an increase in hardness. Thus, as the annealing temperature increases, $\mathrm{Ni}, \mathrm{Ni}_{3} \mathrm{P}$ and $\mathrm{Ni}-\mathrm{Mo}$ phases precipitate, leading to an increase in the hardness of the $\mathrm{Ni}_{78} \mathrm{Mo}_{10} \mathrm{P}_{12}$ coating.

Finally, these hardness measurements suggest that $\mathrm{Ni}-\mathrm{Mo}-\mathrm{P}$ coatings can substitute $\mathrm{Cr}$ coatings in industrial applications that require high operational temperatures and good hardness properties, since it is reported in the literature ${ }^{10,25-27}$ that the hardness of the $\mathrm{Cr}$ coatings drops between $550 \mathrm{Hv}$ and $400 \mathrm{Hv}$ when heat-treatment temperature is in the range of $100{ }^{\circ} \mathrm{C}$ to $600{ }^{\circ} \mathrm{C}$.

\section{Electrochemical measurements}

The influence of $\mathrm{P}$ content on the corrosion behaviour of the Ni-Mo-P coatings is shown in Figure 6. It can be observed that the worst corrosion behaviour is showed by the cracked $\mathrm{Ni}_{81} \mathrm{Mo}_{18} \mathrm{P}_{1}$ coating. For the no cracked $\mathrm{Ni}-\mathrm{Mo}-\mathrm{P}$ samples, it can be observed the beneficial effect of the $\mathrm{P}$ content in the corrosion behaviour, since the corrosion potentials shift to more positive values with the increase of $\mathrm{P}$ content and the lowest anodic current densities are presented by the Ni-Mo-P amorphous coating with highest $\mathrm{P}$ content. The electrochemical parameters derived from the polarisation curves are shown in Table 4.

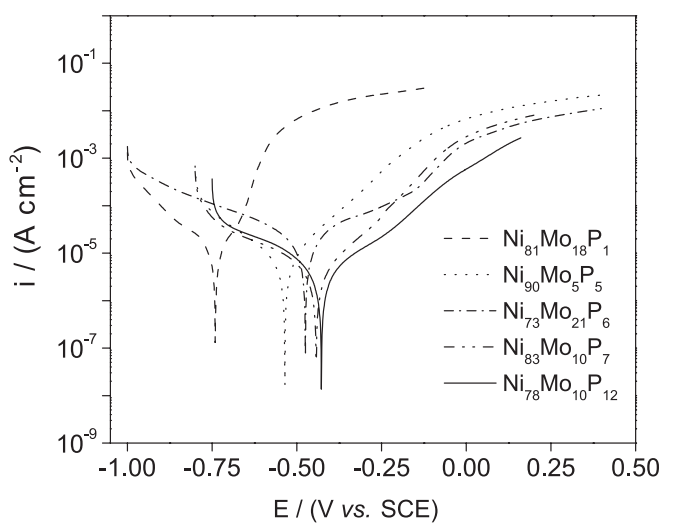

Figure 6. Potentiodynamic polarisation curves obtained in $0.1 \mathrm{~mol} \mathrm{dm}{ }^{-3}$ $\mathrm{NaCl}$ solution for the electrodeposited $\mathrm{Ni}-\mathrm{Mo}-\mathrm{P}$ amorphous coatings.

Table 4. Corrosion parameters derived from the potentiodynamic linear polarisation curves

\begin{tabular}{lcc}
\hline Coating & $-\mathrm{E}_{\text {cor }} /(\mathrm{V}$ vs. SCE $)$ & $\mathrm{R}_{\mathrm{p}} / \mathrm{k} \Omega \mathrm{cm}^{2}$ \\
\hline $\mathrm{Ni}_{81} \mathrm{Mo}_{18} \mathrm{P}_{1}$ & 0.74 & 1.273 \\
$\mathrm{Ni}_{73} \mathrm{Mo}_{21} \mathrm{P}_{6}$ & 0.46 & 2.06 \\
$\mathrm{Ni}_{83} \mathrm{Mo}_{10} \mathrm{P}_{7}$ & 0.45 & 2.237 \\
$\mathrm{Ni}_{90} \mathrm{Mo}_{5} \mathrm{P}_{8}$ & 0.44 & 2.532 \\
$\mathrm{Ni}_{82} \mathrm{Mo}_{5} \mathrm{P}_{12}$ & 0.43 & 2.934 \\
$\mathrm{Ni}_{78} \mathrm{Mo}_{10} \mathrm{P}_{12}$ & 0.43 & 3.13 \\
\hline
\end{tabular}


The analysis of this table reveals that polarisation resistance $\left(\mathrm{R}_{\mathrm{p}}\right)$ increases with an increase in $\mathrm{P}$ content in the layer, and that samples with the same $\mathrm{P}$ content but with higher Mo content present the higher value of $R_{p}$.

\section{Conclusions}

Amorphous Ni-Mo-P coatings were successfully obtained by electrodeposition using direct current. The coating composition showed to be dependent on the bath composition, current density and bath temperature. Both $\mathrm{P}$ and Mo contents contribute for the hardness properties of the Ni-Mo-P coatings and the absence of cracks is a requirement to produce electrodeposited $\mathrm{Ni}-\mathrm{Mo}-\mathrm{P}$ coatings with good hardness properties. The hardness values increases with heat-treatment temperature due to the precipitation of $\mathrm{Ni}, \mathrm{Ni}_{3} \mathrm{P}$ and $\mathrm{NiMo}$ phases during the heat treatment. The corrosion resistance of the electrodeposited $\mathrm{Ni}-\mathrm{Mo}-\mathrm{P}$ amorphous coatings increases with $\mathrm{P}$ content in the layer. Among the electrodeposited Ni-Mo-P amorphous coatings, $\mathrm{Ni}_{78} \mathrm{Mo}_{10} \mathrm{P}_{12}$ presented the best hardness and corrosion-resistance properties. The results showed that the addition of $\mathrm{P}$ is beneficial for the hardness and corrosion resistance properties of the $\mathrm{Ni}-\mathrm{Mo}-$ based coatings.

\section{Acknowledgments}

The authors gratefully acknowledge funding provided by the following Brazilian agencies: CNPq, CAPES, FUNCAP and FINEP. Régis L. Melo gratefully acknowledges the award of a grant by CAPES.

\section{References}

1. Friend, W.Z.; Corrosion of Nickel and Nickel-base Alloys, Wiley Interscience Publication: New York, 1980.

2. Sanches, L. S.; Domingues, S. H.; Marino, C. E. B.; Mascaro, L. H.; Electrochem. Commun. 2004, 6, 543.

3. Brooman, E. W.; Met. Finish. 2000, 102, 38 and references cited therein.

4. Brooman, E. W.; Met. Finish. 2000, 102, 39 and references cited therein.

5. Gennero de Chialvo, M. R.; Chialvo, A. C.; J. Electroanal. Chem. 1998, 448, 87.

6. Kubisztal, J.; Budniok, A.; Int. J. Hydrogen Energ. 2008, 33, 4488.
7. Krstajić, N. V.; Jović, V. D.; Gajić-Krstajić, Lj.; Jović; B. M.; Antozzi, A. L.; Marteli, G. N.; Int. J. Hydrogen Energ. 2008, 33, 3676 .

8. Han, Q.; Cui, S.; Pu, N.; Chen, J.; Liu, K.; Wei, X.; Int. J. Hydrogen Energ. 2010, 35, 519.

9. Tsenta, T. E.; Knyazheva, V. M.; Svistunova, T. V.; Kolotyrkin, Y. M.; Zakharin, D. S.; Prot. Met. 1989, 25, 28.

10. De Lima-Neto, P.; Correia, A. N., Vaz, G. L.; Casciano, P. N. S.; J. Braz. Chem. Soc. 2010, 21, 1968.

11. Emsley, J.; The Elements, $3^{\text {rd }}$ ed., Clarendon Press: Oxford, United Kingdom, 1998.

12. Chassaing, E.; Portail, N.; Levy, A. F.; Wang, G.; J. Appl. Electrochem. 2004, 34, 1085.

13. Waseda, Y.; Aust, K. T.; J. Matter. Sci. 1981, 16, 2337.

14. Luborsky, F. E.; Amorphous Metallic Alloys, Butterworths: London, 1983.

15. Archer, M. D.; Corke, C. C.; Hargi, B. H.; Electrochim. Acta 1987, 32, 13

16. Searson, P. C.; Nagarkar, P. V.; Latanision, R. M. In Modern Aspects of Electrochemistry; White, R. E.; Bockris, J. O'M; Conway, B. E., eds.; Plenum Press: New York, 1990, vol. 21.

17. Tsyntsaru, N.; Bobanova, J.; Cesiulis, H.; Dikusar, A.; Prosycevas, I.; Celis, J. P.; Surf. Coat. Technol. 2009, 203, 3136.

18. Tharamani, C. N.; Beera, T.; Jayaram, V.; Begum, N. S.; Mayanna, S. M.; Appl. Surf. Sci. 2006, 253, 2031.

19. Doten, M.; Cesilius, H.; Stojek, Z.; Electrochim. Acta 2005, 50, 1405.

20. Królikowki, A.; Plońska, E.; Ostrowski, A.; Doten, M.; Stojek, Z.; J. Solid State Electrochem. 2009, 13, 263.

21. Weston, D. P.; Harris, S. J.; Shipway, P. H.; Weston, N. J.; Yap, G. N.; Electrochim. Acta 2010, 55, 5695.

22. De Lima Neto, P.; Rabelo, F. J. B.; Adam, A. M. M. M.; Gonzalez, E. R.; Avaca, L. A.; Quim. Nova 1996, 19, 345.

23. Marlot, A.; Kern, P.; Landolt, D.; Electrochim. Acta 2002, 48, 29.

24. Liu, D. L.; Yang, Z. G.; Zhang, C.; Mater. Sci. Eng., B 2010 , 166, 67.

25. De Lima-Neto, P.; Correia, A. N., Vaz, G. L.; Cassiano, P. N. S.; J. Electrochim. Acta 2010, 55, 2078.

26. De Lima-Neto, P.; Da Silva, G. P.; Correia, A. N.; Electrochim. Acta 2006, 51, 4928.

27. De Lima-Neto, P.; Correia, A. N.; Da Silva, G. P.; J. Braz. Chem. Soc. 2006, 17, 1419.

28. Koiwa, I.; Usuda, M.; Yamada, K.; Osaka, T.; J. Electrochem. Soc. 1988, 135, 718 .

Submitted: March 15, 2011

Published online: December 15, 2011 